\title{
Variations in Stolon Length and Tuber Roots Among Six Potato Cultivars
}

\author{
Bulti Merga $^{1} \&$ Nigussie Dechassa ${ }^{1}$ \\ ${ }^{1}$ School of Plant Sciences, Haramaya University, Ethiopia \\ Correspondence: Bulti Merga, School of Plant Sciences, Haramaya University, Ethiopia. E-mail: \\ bultimerga@gmail.com
}

Received: November 30, 2018

Accepted: January 12, $2019 \quad$ Online Published: March 15, 2019

doi:10.5539/jas.v11n4p563

URL: https://doi.org/10.5539/jas.v11n4p563

\begin{abstract}
This study is tested whether the stolon length and tuber roots show variations and could affect potato yield among the potato cultivars over two cropping seasons. Six potato cultivars from a group of improved and local cultivars were examined. The results of the experiments done during both seasons revealed that the stolon length and tuber roots showed variations within and among cultivars. Also a relationship between the length of the stolon and yield of tubers was found. The strongest correlations involved from the stolon length and the tuber roots with the increase in tuber yield under the improved cultivars, then the local cultivar with the decrease in yield. These correlations were positive: the higher the value of the parameter, the greater the observed increase in yield with improved cultivars. This showed a relationship between stolon length and tuber roots with the increase of yield; this relationship was stronger for roots in improved cultivars than in the local cultivar. Therefore, this study indicates that improved potato cultivars with deep root systems might improve tuber yields in eastern highlands of Ethiopia.
\end{abstract}

Keywords: fertilizer placement, Solanum tuberosum, stolon roots, tuber weight

\section{Introduction}

Potato (Solanum tuberosum L.) is the third most important food crop after rice and wheat for human consumption and over a million people on earth eat potatoes (CIP, 2014). Potato is also the most important tuber crop, ranking first in volume produced among root and tuber crops, with an annual production of approximately 320 million tones grown on about 20 million hectares; it is followed by cassava, sweet potato, and yam (FAO, 2008). Potato is grown in more than 150 countries worldwide from latitudes $65^{\circ} \mathrm{N}$ to $50^{\circ} \mathrm{S}$ and from sea level to 4000 meters above sea level (Acquaah, 2007). In 2007 the potato production reached a record of 325 million metric tons becoming the first non-grain commodity for the humanity (FAO, 2009). However demand for both food and energy is rising and it is expected to keep the same trend with increases in global population and average income (Lobell et al., 2009). Asia and Europe are the world's major potato producing regions, accounting for more than $80 \%$ of world production, while Africa produces the least, accounting for about $5 \%$ (FAO, 2008). North America is the clear leader in productivity at more than $40 \mathrm{t} \mathrm{ha}^{-1}$, followed by Europe at 17.4 $\mathrm{t} \mathrm{ha}^{-1}$, while Africa lags at about $10 \mathrm{t} \mathrm{ha}^{-1}$ (FAO, 2008). The average yield of potato in Ethiopia ranges only between 8 to $10 \mathrm{t} \mathrm{ha}^{-1}$, which is much lower than the yields obtained even in Sudan $\left(17 \mathrm{t} \mathrm{ha}^{-1}\right)$ and Egypt $(26 \mathrm{t}$ $\mathrm{ha}^{-1}$ ) (Haverkort et al., 2012).

Stolons of potato plants represent modified lateral shoots which arise from nodes at the base of the shoot system, below the soil. They differ from normal green shoots in having elongated internodes, hooked tips, small scale-leaves, lack of chlorophyll and a diageotropic habit. Differences in stolon length and depth have previously been identified between cultivars (Firman 1995, 1996) but it is uncertain how consistent these differences are and the extent to which the environment can affect them.

Morphologically, potato stolons are lateral stems which grow horizontally below ground from buds of the underground part of stems. The length of stolons is an important varietal character. Long stolons are common in wild potatoes, potato breeding aims at short stolons. Stolons may eventually form tubers by enlargement of their terminal end. However, not all stolons may form tubers. A stolon not covered by soil may develop into a vertical stem with normal foliage (Zosimo Huaman, 1986). 
In Ethiopia there is almost no scientific information which indicates the yield gap observed among potato cultivars in general. The below-ground development of potato crop is poorly understood. Farmers have been using haphazardly their own potato seed which is not tested and proved through research. In Eastern Hararghe Zone, potato is one of the cash crops which play a significant role in improving farmers' income and food sustainability.

The major contributing factors to the low yields of potato have been the use of poorly adapted cultivars, high prevalence of diseases and pests, poor soils, unfavorable weather conditions, un-scientific cultural practices including tuber planting depth (Snapp \& Kravchenko, 2010). The problems related to the use of appropriate potato cultivars with their economic importance, optimum growth of stolon in each potato cultivars as well as the average stolon length among cultivars need assessment for efficient use of nutrient in soil. The objectives of this study are to quantify the length of stolons, the depth at which they attached to the stem, and how this differs between cultivars, and assess the tuber yield gap among potato cultivars.

\section{Materials and Methods}

The field experiment was conducted during 2016 and 2017 main rain season, at Haramaya University Raaree Research farm. The site is located at 2020 meters above sea level, $9^{\circ} 41^{\prime} \mathrm{N}$ latitude and $42^{\circ} 03^{\prime} \mathrm{E}$ longitude. The area receives an annual rainfall of $760 \mathrm{~mm}$ with bimodal rainfall pattern and average maximum and minimum temperatures of $23.4{ }^{\circ} \mathrm{C}$ and $8.25{ }^{\circ} \mathrm{C}$, respectively. The area has a bimodal rainfall distribution and is representative of a sub-humid mid-altitude agro-climatic zone. The short rainy season extends from March to April and constitutes about $25 \%$ of the annual rainfall whereas the long rainy season extends from June to October and accounts for about $45 \%$ of the total rainfall (Belay et al., 1998).

The soil of the experimental site is a well-drained deep alluvial with a sub-soil stratified with loam and sandy loam (Tamire, 1973). The chemical properties of the soil indicated that the soil has organic carbon content of $1.15 \%$, total nitrogen content of $0.11 \%$, available phosphorus content of $18.2 \mathrm{mg} \mathrm{kg} \mathrm{soil}{ }^{-1}$, exchangeable potassium content of $0.65 \mathrm{c} \mathrm{mol} \mathrm{kg} \mathrm{soil}^{-1}\left(255 \mathrm{mg}\right.$ exchangeable $\left.\mathrm{K} \mathrm{kg} \mathrm{soil}^{-1}\right), \mathrm{pH}$ of 8.0 . The physical properties of the soil indicated sand, silt, and clay contents of 63,20 , and 17 percentages respectively, which is sandy clay (Simret et al., 2014).

The treatments consisted of six cultivars of potato (Challa, Zemen, Gebisa, Bubu, Jalene, and Bule). The first five consecutive cultivars are improved while the last one is a local potato cultivar. The experiment was laid out with Randomized Complete Block Design (RCBD) in factorial arrangement and replicated three times. The land was prepared in accordance with a standard practice of Haramaya University (HURC, 1996). The experimental plot was cultivated to a depth of $25-30 \mathrm{~cm}$ using tractor. In order to create a good seed bed for proper crop growth, the experimental field was cleared and ploughed and disked three times using tractor.

Medium sized potato tubers with sprouts measuring about 1.5 to $2.5 \mathrm{~cm}$ were planted on prepared ridges at the spacing of $75 \mathrm{~cm}$ between rows and $30 \mathrm{~cm}$ between plants. Plot size was $3.6 \mathrm{~m} \times 4.5 \mathrm{~m}\left(16.2 \mathrm{~m}^{2}\right), 6$ rows per plot and 12 hills per row. Hence, there were 72 hills per plot. Regular hoeing was done for control of weeds.

The full dose of phosphorus was applied at planting time in prepared ridges by banding the granules at the depth of $10 \mathrm{~cm}$ below the seed tuber. Nitrogen fertilizer was side dressed in three splits: one-third at planting; one-third at active vegetative stage (about 50 days after planting) and the remaining one-third just before the start of flowering or tuber initiation.

Weeding, cultivation and earthing-up and ridging were done at the appropriate time to facilitate root, stolon and tuber growth. Weeds were controlled by hoeing and earthing-up as required to prevent exposure of tubers to direct sun light and for promoting tuber bulking and for ease of harvesting. Other cultural practices were applied as per the usual practices used by Haramaya University to grow potato crops. To avoid bruising and skinning of tubers during harvesting and post-harvest handling, the haulms were mowed two weeks before harvesting to thicken tuber periderm. Mowing of haulms was carried out when the plants reached physiological maturity, i.e. when yellowing or senescence was apparent on the lower leaves. 40 plants were harvested from a net plot area of $3 \mathrm{~m} \times 3 \mathrm{~m}\left(9 \mathrm{~m}^{2}\right)$, leaving aside all plants at the border rows as well as those at both ends of each row to avoid edge effects, to estimate tuber yield and other yield-related parameters. Nitrogen was applied as urea ( $46 \% \mathrm{~N})$, $7-10 \mathrm{~cm}$ away from the plant as three times split applications where $1 / 3$ during emergency, $1 / 3$ during tuber initiation, and the last $1 / 3$ will be at enlargement of tubers or bulking (Vitosh et al., 1997).

Data on stolon length, stolon number and tuber number were determined from 5 plants randomly sampled from each plot just at physiological maturity. Total tuber yields and numbers were recorded as the sum of marketable and unmarketable tuber yields and numbers, respectively. 
The data were subjected to analysis of variance (ANOVA) of RCBD in factorial arrangements for each season using the general linear model of Genstat $16^{\text {th }}$ edition up dated version. Treatment means that exhibited the significant differences were separated using Fisher's unprotected least significant difference test at $5 \%$ level of significance.

\section{Results}

\subsection{Stolon Length (cm)}

Bubu cultivar produced the tallest stolon for both growing seasons $7.36 \mathrm{~cm}$ and $7.20 \mathrm{~cm}$ in 2016 and 2017 , respectively. Bule produced the shortest stolon $(1.9 \mathrm{~cm})$ during the first crop growing season whereas, Zemen cultivar revealed the shortest solon length $(5.96 \mathrm{~cm})$ among all cultivars of the second growing season (2017). In different countries, many scientists have indicated the significant effect of seed tuber planting depth on the yield and yield components of potato. (Abdulla et al., 1993; Bohl Love, 2005) reported that potato yield increase when planting depth increases, with a small tuber greening effect. Seed tuber planting depth plays an essential role in formation of stolons and aerial potato stems so that stolon numbers and ultimately the yield itself will decrease with higher planting tuber depths (up to approximately $20 \mathrm{~cm}$ depth, depending on crop conditions) (Ezekiel et al., 1992). A field experiment done in Iran on clay loamy soil indicated higher overall performance at $10 \mathrm{~cm}$ planting depth than 15 and $25 \mathrm{~cm}$ depths (Laei et al., 2012).

Table 1. Comparison of stolon length, stolon number and tuber number parameters among six potato cultivars on yield related traits

\begin{tabular}{|c|c|c|c|c|c|c|}
\hline \multirow{2}{*}{ Treatment } & \multicolumn{2}{|c|}{ Stolon Length $(\mathrm{cm})$} & \multicolumn{2}{|c|}{ Stolon Number } & \multicolumn{2}{|c|}{ Tuber Number } \\
\hline & 2016 & 2017 & 2016 & 2017 & 2016 & 2017 \\
\hline Challa & $4.15^{\mathrm{bc}}$ & $7.00^{\mathrm{ab}}$ & $22.07^{\mathrm{b}-\mathrm{d}}$ & $16.27^{\mathrm{b}-\mathrm{e}}$ & $15.67^{\mathrm{ab}}$ & $7.4^{\mathrm{ab}}$ \\
\hline Zemen & $4.73^{\mathrm{b}}$ & $5.96^{\mathrm{b}-\mathrm{e}}$ & $26.60^{\mathrm{ab}}$ & $12.33^{\mathrm{de}}$ & $17.27^{\mathrm{a}}$ & $4.40^{\mathrm{c}}$ \\
\hline Bubu & $7.36^{\mathrm{a}}$ & $7.20^{\mathrm{a}}$ & $29.80^{\mathrm{a}}$ & $14.33^{\mathrm{c}-\mathrm{e}}$ & $16.67^{\mathrm{ab}}$ & $4.93^{\mathrm{bc}}$ \\
\hline Jalene & $4.81^{\mathrm{b}}$ & $6.16^{\mathrm{b}-\mathrm{d}}$ & $20.13^{\mathrm{b}-\mathrm{e}}$ & $23.6^{\mathrm{a}}$ & $13.6^{\mathrm{b}-\mathrm{e}}$ & $8.60^{\mathrm{a}}$ \\
\hline Bete & $3.33^{\mathrm{b}-\mathrm{d}}$ & $6.49^{\mathrm{b}-\mathrm{d}}$ & $20.47^{\mathrm{b}-\mathrm{e}}$ & $18.67^{\mathrm{a}-\mathrm{c}}$ & $13.93^{\mathrm{b}-\mathrm{e}}$ & $5.53^{\mathrm{bc}}$ \\
\hline Bule & $1.9^{\mathrm{d}}$ & $6.54^{\mathrm{b}-\mathrm{d}}$ & $16.93^{\mathrm{de}}$ & $11.60^{\mathrm{e}}$ & $12.07^{\mathrm{c}-\mathrm{e}}$ & $4.42^{\mathrm{c}}$ \\
\hline $\operatorname{LSD}(5 \%)$ & 1.996 & 2.284 & 6.797 & 5.856 & 4.024 & 2.69 \\
\hline $\mathrm{CV}$ & 29.8 & 22.3 & 19.7 & 21.9 & 16.9 & 28.3 \\
\hline F test & $*$ & $*$ & $*$ & $*$ & $*$. & $*$ \\
\hline
\end{tabular}

Note. Means with the same letter(s) within a column are not significantly different at $5 \%$ level of significance. $\mathrm{NS}=$ non-significant difference, $\operatorname{LSD}(5 \%)=$ Least significant difference at $\mathrm{P}=0.05, \mathrm{CV}(\%)=$ Coefficient of variation in percent, and $*=\mathrm{F}$ test significantly different at $5 \%$.

\subsection{Stolon Number per Hill}

During the first experimental season (2016) Bubu generated the greatest number of stolons $\left(29.80 \mathrm{hill}^{-1}\right)$, was shown no significant difference from Zemen $\left(26.60\right.$ hill $\left.^{-1}\right)$, but was significantly different from all other potato cultivars included in this study. Bule showed the lowest number of stolons $\left(16.93 \mathrm{hill}^{-1}\right)$, among all cultivars. In other ways, potato cultivar Jalene showed the greatest number of stolons $\left(23.6\right.$ hill $\left.^{-1}\right)$ during 2017, which was not significantly different from Bete with a number of stolons $\left(18.67\right.$ hill $\left.^{-1}\right)$. Bule revealed the lowest number of stolons (11.6 hill $\left.{ }^{-1}\right)$, among all potato cultivars. In a sandy loam soil in the Tunisia, two potato cultivars planted at the seed tuber depth of $15 \mathrm{~cm}$ outperformed those planted at a $10 \mathrm{~cm}$ depth (Sayed et al., 2013). The mechanism controlling these patterns appears to operate at the level of the node and the position of a node in the hierarchy seems to be a major determinant of number of stolons and tubers and tuber yield. 


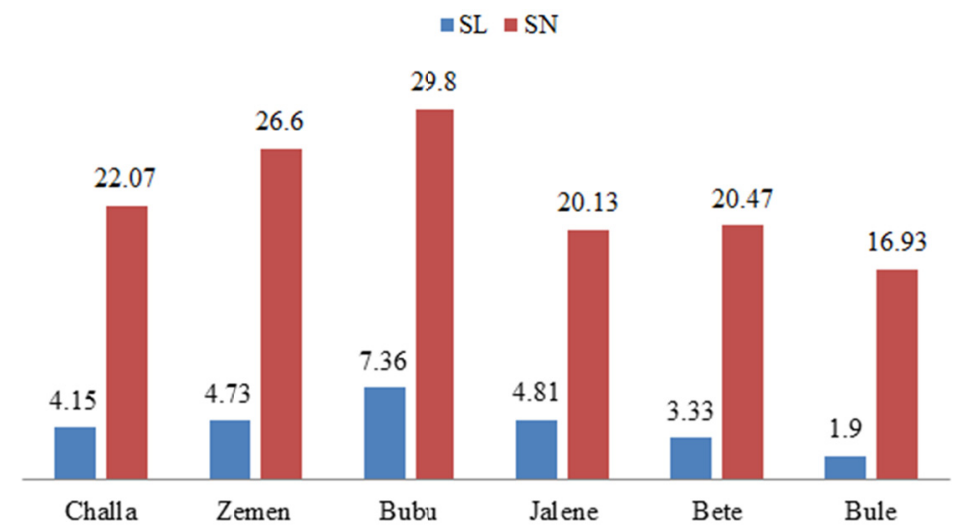

Figure 1. The correlation between stolon length and stolon number during 2016 growing season. "Tt" represents total tuber yield, "SL" represents stolon length

\subsection{Number of Tubers per Hill}

Zemen potato cultivar generated the greatest number of tubers $\left(17.27 \mathrm{hill}^{-1}\right)$, but there was no significant difference with Challa $\left(16.67\right.$ hill $\left.^{-1}\right)$ and Bubu $\left(16.67\right.$ hill $\left.^{-1}\right)$ while significant differences observed with the rest of cultivars. In other way, potato cultivar Jalene, showed greatest number of tubers $\left(8.6\right.$ hill $\left.^{-1}\right)$, for the second growing season (2017), which was not significantly different from Challa with a number of tubers $\left(7.4\right.$ hill $\left.^{-1}\right)$. Other cultivars were not statistically different and exhibited the lowest number of tubers per hill among cultivars. Similarly, Gholipour (1996) reported that number of tubers plant ${ }^{-1}$ and unit area ${ }^{-1}$ decreased as planting depth increased and the studies also revealed that the reduction of stem number was the cause for the reduction of tubers plant ${ }^{-1}$ and unit area ${ }^{-1}$. Several factors can affect the depth of planting potatoes which include seed quality, soil moisture and temperature (Van der Zaag, 1989).

Table 2. Comparison of marketable and total tuber yield parameters among six potato cultivars on yield related traits

\begin{tabular}{llllll}
\hline \multirow{2}{*}{ Treatment } & \multicolumn{2}{c}{ Marketable Tuber $\left(\mathrm{t} \mathrm{ha}^{-1}\right)$} & & \multicolumn{2}{c}{ Total Yield $\left(\mathrm{t} \mathrm{ha}^{-1}\right)$} \\
\cline { 2 - 3 } \cline { 5 - 6 } & 2016 & 2017 & 2016 & 2017 \\
\hline Challa & $22.68^{\mathrm{cd}}$ & $23.11^{\mathrm{cd}}$ & & $28.84^{\mathrm{a}-\mathrm{d}}$ & $27.64^{\mathrm{c}-\mathrm{e}}$ \\
Zemen & $24.74^{\mathrm{b}-\mathrm{d}}$ & $28.44^{\mathrm{bc}}$ & & $32.6^{\mathrm{a}-\mathrm{c}}$ & $32.12^{\mathrm{b}-\mathrm{d}}$ \\
Bubu & $31.66^{\mathrm{a}}$ & $37.92^{\mathrm{a}}$ & & $35.16^{\mathrm{a}}$ & $43.63^{\mathrm{a}}$ \\
Jalene & $28.51^{\mathrm{a}-\mathrm{c}}$ & $35.41^{\mathrm{ab}}$ & & $34.42^{\mathrm{ab}}$ & $41.42^{\mathrm{ab}}$ \\
Bete & $21.41^{\mathrm{d}}$ & $22.69^{\mathrm{cd}}$ & & $27.31^{\mathrm{d}}$ & $26.61^{\mathrm{c}-\mathrm{e}}$ \\
Bule & $14.31^{\mathrm{e}}$ & $23.11^{\mathrm{cd}}$ & & $18.26^{\mathrm{e}}$ & $26.85^{\mathrm{c}-\mathrm{e}}$ \\
LSD $(5 \%)$ & 6.899 & 9.029 & & 6.645 & 10.253 \\
CV & 17.5 & 19.8 & & 13.6 & 19.2 \\
F test & $*$ & $*$ & $*$ & $*$ \\
\hline
\end{tabular}

Note. Means with the same letter(s) within a column are not significantly different at $5 \%$ level of significance. $\mathrm{NS}=$ non-significant difference, $\mathrm{LSD}(5 \%)=$ Least significant difference at $\mathrm{P}=0.05, \mathrm{CV}(\%)=$ Coefficient of variation in percent, and $*=\mathrm{F}$ test significantly different at $5 \%$.

\subsection{Marketable Tuber Yield}

The potato cultivar, Bubu showed the highest yield $\left(31.66 \mathrm{tha}^{-1}\right)$, which was not significantly different from that of Jalene with a yield of $28.51 \mathrm{tha}^{-1}$. Bule exhibited the lowest yield of $14.31 \mathrm{t} \mathrm{ha}{ }^{-1}$, among all cultivars of the first growing season (2016) (Table 2). Similarly, Bubu revealed the highest yield $37.92 \mathrm{t} \mathrm{ha}^{-1}$, but was not statistically different from Jalene (35.41 $\left.\mathrm{t} \mathrm{ha}^{-1}\right)$. Challa and Bule were exhibited the lowest yield $\left(23.11 \mathrm{t} \mathrm{ha}^{-1}\right)$ among all cultivars, but was not statistically different from Bete $\left(22.69 \mathrm{t} \mathrm{ha}^{-1}\right)$ cultivar of the second growing season (2017).This result is in line with the findings in which Bubu potato cultivar produce the highest tuber yield from same study area with this field experiment (33.48 $\mathrm{t} \mathrm{ha}^{-1}$ ), (Mohammed, 2014). Nitrogen is one of the 
essential elements for plant growth and is one of main components of proteins. When plants were fertilized with overdose of nitrogen, protein production decrease and nitrogen was found be stored as non-protein form (Molerhagen, 1993). Nitrate is one of the non-protein forms which are poisonous for human or stock. On the other hand, different cultivars have different rates of nitrogen for maximum tuber yields (Molerhagen, 1993).

\subsection{Tuber Yield}

The cultivar Bubu showed the highest yield $\left(35.16 \mathrm{t} \mathrm{ha}^{-1}\right)$, which was not significantly different from that of Jalene, and Zemen, with yield of 34.42 and $32.6 \mathrm{t} \mathrm{ha}^{-1}$, respectively. Bule cultivar exhibited the lowest yield of $18.26 \mathrm{t} \mathrm{ha}^{-1}$, among all cultivars of the first growing season (2016) (Table 2). Similarly, Bubu revealed the highest yield $43.63 \mathrm{t} \mathrm{ha}^{-1}$, but, was not statistically different from Jalene $\left(41.42 \mathrm{t} \mathrm{ha}^{-1}\right)$. Bete cultivar exhibited the lowest yield $\left(26.61 \mathrm{t} \mathrm{ha}^{-1}\right)$ among all cultivars, but was not statistically different from other low yielded cultivars used in this experiment. Tuber weight depends primarily on the operating time of the leaf canopy (Snapp \& Kravchenko, 2010), but also the conditions of operation and conditions of root growth.

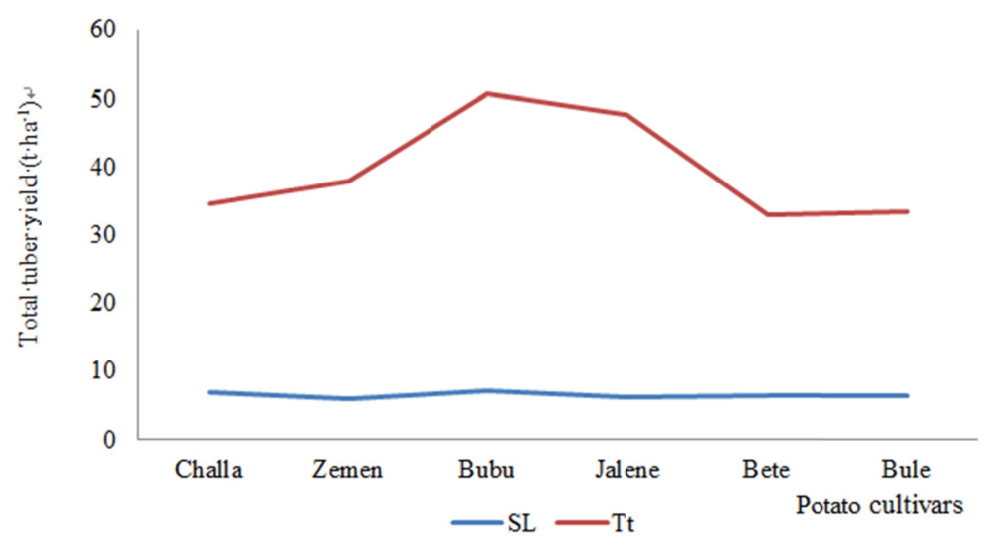

Figure 2. The correlation between stolon length and total tuber yield for the second growing season (2017). "Tt" represents total tuber yield, "SL" represents stolon length

\section{Discussions}

On the supply side, experts consider that maximum possible yields for major cereals achieved in farmers' fields might level off or even decline in many regions over the few decades to come (Lobell et al., 2009). That means potatoes still have a high potential to solve the food shortage especially in countries where farmers' yields are still low from the potential ones-existence of huge yield gaps-since it's known that food supply is a mathematical product of crop area by yield.

Potato cultivars has their own packages of recommendations which includes planting date, planting methods, tuber planting depth, fertilizer application, maturity dates, harvesting methods and shelf life time. All these factors are the core to cause stolon length, tuber roots and yield variations in potato crop productions and need to be considered by government and farmers to get profit from growing potato.

For instance, in line with this finding Lambion et al. (2006) advocated that deeper planting may also limit tuber bulking due to soil compaction or damage of tubers by certain pests. Blanket recommendation of long years, 146 $138^{-1} \mathrm{~kg} \mathrm{ha}^{-1} \mathrm{~N} \mathrm{P}_{2} \mathrm{O}_{5}^{-1}$ was recommended as economic and agronomic rate of fertilizer for the highlands of Hararghe (Teressa, 1995). The fertilizer recommendations should be area specific and based on recent plant tissue analysis or soil test for essential elements. Rosen and McNearney (2003) argued that to get more marketable tubers extra nutrients were needed. Hence, deeper planting and potato cultivar that have long stolon is important. Concurrent with the results of this study, Pavek and Thornton (2009) reported that marketable yield and gross income declined typically when seed pieces were planted at shallower depths. The authors also explained that the largest impact on marketable yield and gross income reduction might be due to shallower seed tuber planting depth which attribute to greening of tubers, when seed tuber pieces were planted deeper, the incidences of tuber greening was recorded.

Marketable yield and gross income typically declined when seed pieces were planted at a shallow depth of $10 \mathrm{~cm}$ (Pavek \& Thornton, 2009). Stolon grows slightly in horizontal direction and elongated to use available phosphorus in the soil. Bubu produced long stolon and used phosphorus more efficiently, and revealed high yield. 
This study showed that potato cultivar which has long stolon produced high tuber yield. Potatoes have a relatively high nutrient requirement and small root system (Stark \& Love, 2003). In this experiment the phosphorus placement was carried out in band application method. Band application method used during planting was with $10 \mathrm{~cm}$ below the potato tuber. Research shows that, in most situations, a combination of broadcast and banding is beneficial (Hopkins \& Ellsworth, 2005a, 2005b). Phosphorus is often deficient in alkaline soils, because it is tied up in insoluble calcium or magnesium phosphates (e.g. $\left(\mathrm{Ca}_{3}\left(\mathrm{PO}_{4}\right)_{2}\right)$. Although the concentrated fertilizer bands may not be improving early season nutrition and growth, final tuber quality does seem to be impacted favorably (Hopkins \& Ellsworth, 2006), suggesting that the mid to late season contribution may be important.

Various crop species to absorb $\mathrm{P}$ depends on the amount of available $\mathrm{P}$ in the soil and the ability of the root to absorb and accumulate $\mathrm{P}$ in the shoots. Root surface and density are highly related to crop $\mathrm{P}$ absorption efficiency (Loneragan \& Asher, 1967). Crops with limited root systems show a higher response to fertilizer if placed near the seed than crops that have an extensive root system, particularly in soils with low concentrations of available P (Rodríguez, 1993).

This experimental field revealed that the growth trait and tuber yield of the potato crop during 2017 experimental season is significantly higher than that of 2016. The main cause for the superior growth and yield parameters of the crop during 2017 than 2016 may be attributed to variations in soil chemical properties and inherent soil texture between the two experimental seasons, mainly due to the genetic attributes of potato cultivars for adaptability to different chemical properties of the soil. Potatoes can grow under a wide range of soil $\mathrm{pH}$ varying from neutral to alkaline reaction (Jadhav \& Kadam, 1998; Fageria et al., 2011). However, the soil pH for optimum yield the crop ranges from 5.0-6.5 (McLean \& Brown, 1984). The $\mathrm{pH}$ of Haramaya Raaree experimental farm site is alkaline. This means the potato crop is grown under sub-optimal $\mathrm{pH}$ in most of the surveyed farms in informal way. The effects of high soil $\mathrm{pH}$ on potato crop include low availability of phosphorus nutrient (Holford, 1997). Alkaline soils also favour potato skin diseases such as common scab (Streptomyces scabies) (Jadhav \& Kadam, 1998). Thus, in such soil, seedlings would require more energy to emerge, with curtailed potential of subsequent growth and productivity of the crop.

\section{Conclusions}

This study is attempted to elucidate the stolon length, tuber roots and yield differences observed though similar cultural practices provided for all potato cultivars included in two experimental seasons. The blanket recommendation of fertilizer rate is currently under usage from many people of Ethiopian potato growers regardless of cultivars specific fertilizer requirement. The variation of the potato tuber yield is revealed within and among cultivars at same study farm. To enhance their economy and sustain livelihood to reduce countrys' poverty, farm households should plant improved potato cultivars, Bubu and Jalene, which are revealed the highest yield at the experimental farm through efficiently using the applied fertilizer for crop production. Bubu potato cultivar has long stolon and showed high tuber yield in both crop growing seasons. The results of this study indicated that Bubu is a noble potato cultivar for production at Haramaya crop growing area. Moreover, it is produced the tallest stolon, the greatest number of tubers per hill, the greatest weight of tubers per hill, and the highest tuber yield per hectare during two consecutive potato crop growing seasons. Furthermore, Bubu potato cultivar is showed the greatest marketable tuber yield which is very important for selling to the foreign and domestic market as raw or processed form. Bubu improved potato is the most favorite cultivar by farmers at the study area. Bule cultivar is, on the other hand, exhibited the shortest stolon length, low weight of tuber per hill, and low yield, per comparison to the other cultivars. Bule local potato cultivar has low resistance to potato diseases compare to Bubu cultivar. In conclusion, this field experiment is recommended an idea that farmers at Haramaya farm area should cultivate Bubu potato cultivar for its high tuber yield and resistance to lateblight crop diseases. Jalene potato cultivar is the second best candidate for potato production in Haramaya if disease management tools are available. Potato growers should select improved potato cultivar which has long stolon, high tuber roots and yield, and resistant or tolerant to late blight disease to sustain their livelihood and obtain economically high profit from the marketing of potato crop to play substantial role in countrys' poverty reduction.

\section{References}

Acquaah, G. (2007). Principles of plant genetics and breeding. Blackwell Publishing Ltd., Malden, MA, USA.

Berga, L., Gebremedhin, W., Terrisa, J., Bereke, T. T., \& Yaynu, H. (1994). Potato Improvement Research. In H. Edward, \& D. Lemma (Eds.), Proceedings of the Second National Horticultural Workshop. Addis Ababa, Ethiopia. 
Bohl, W. H., \& Love, S. L. (2005). Effect of planting depth and hilling practices on total, US No. 1, and field greening tuber yields. American Journal of Potato Research, 82(6), 441-450. https://oi.org/10.1007/ BF02872222

Burga, S., Dechassa, N., \& Tsegaw, T. (2014). Influence of Mineral Nitrogen and Potassium Fertilizers on Ware and Seed Potato Production on Alluvial Soil in Eastern Ethiopia. East African Journal of Sciences, 8(2), 155-164.

Chehaibi, S., Hamdi, W., \& Abrougui, K. (2013). Effects of planting depth on agronomic performance of two potato varieties grown in the Sahel region of Tunisia. Journal of Development and Agricultural Economics, 5(7), 272-276. https://doi.org/10.5897/JDAE12.116

CIP (International Potato Center). (2014). Potato. International Potato Center.

Ezekiel, R., Shekhawat, G. S., Sukumaran, N. P., \& Verma, S. C. (1992). Guide to potato processors in India.

Fageria, N. K., Baligar, V. C., \& Jones, C. A. (2011). Growth and Mineral Nutrition of Field Crops (Vol. 3, p. 530). Taylor and Francis Group, New York.

FAO (Food and Agricultural Organization). (2008). Work shop to commemorate the international year of the potato.

FAO (Food and Agricultural Organization). (2009). New light on a hidden treasure (p. 148). FAO, Rome.

Firman. (1995). Report of work on potato blemishing diseases and seed production. CUPGRA Annual Report 1994 (pp. 43-51).

Firman. (1996). Report of work on potato blemishing diseases, seed production and variation in number of stems. CUPGRA Annual Report 1995 (pp. 71-81).

Gholipour, M. (1996). Determination of most favorite tuber weight and planting depth, yield assessment and growth analysis (MSc Thesis, Tabriz University, Iran).

Haverkort, A. J., Koesveld, M. J. Van, Schepers, H. T. A. M., Wijinands, J. H. M., Wustman, R., \& Xiao, Y. Z. (2012). Potato prospects for Ethiopia: On the road to value addition (PPO Publication, No. 528, p. 66). Lelystad: PPO-AGV.

Holford, I. C. R. (1997). Soil phosphorus: Its measurement, and its uptake by plants. Australian Journal of Soil Research, 23, 417-427. https://doi.org/10.1071/SR9850417

Hopkins, B., \& Ellsworth, J. (2005). Phosphorus availability with alkaline/calcareous soil. In K. Copeland, et al. (Eds.), Proceedings of the Winter Commodity Schools-2005 (Vol. 37, pp. 9-18). University of Idaho-Cooperative Extension System, Moscow, Idaho.

Hopkins, B. G., \& Ellsworth, J. W. (2005b). Phosphorus Availability with Alkaline/Calcareous Soil. In W. B. Stevens (Ed.), Western Nutrient Management Conference Proceedings (pp. 88-93). Potash and Phosphate Institute, Norcross Georgia.

Hopkins, B. G., \& Ellsworth, J. W. (2006). Starter Band Placement for Potatoes in Calcareous Soil. In L. Murphy (Ed.), Fluid Forum Proceedings (Vol. 23, pp. 88-95). Fluid Fertilizer Foundation, Manhattan, Kansas.

Huaman, Z. (1986). Systematic botany and morphology of the potato. Technical Information Bulletin 6. International Potato Center, Lima, Peru. Retrieved from http://agris.fao.org/agris-search/search.do?record $\mathrm{ID}=\mathrm{QP} 8900005$

Jadhav, S. J., \& Kadam, S. S. (1998). Potato Production. In D. K. Salunke, \& S. S. Kadam (Eds.), Handbooks of Vegetable Science and Technology, Production, Composition, Storage, and Processing (pp. 13-69). Marcel Dekker, Inc., New York.

Kratzke, M. G., \& Palta, J. P. (1992). Variations in stolon length and in incidence of tuber roots among eight potato cultivars. American Potato Journal, 69(9), 561-570. https://doi.org/10.1007/BF02852128

Laei, G. H., Noryan, M., \& Afshari, H. (2012). Determination of the planting depth of potato seed tuber yield and yield components of two varieties agria and draga response curves seed. Ann Biol Res, 12, 5521-5528.

Lambion, J., Toulet, A., \& Traente, M. (2006). Plant protection cultivation of organic potato, Fact 2: The fight against pests (p. 4). Institute of Agricultural Technology, Paris, France. 
Lobell, D. B., Cassman, K. G., \& Field, C. B. (2009). Crop yield gaps: Their importance, magnitudes, and causes. Annual Review of Environment and Resources, 34, 179-204. https://doi.org/10.1146/annurev.environ. 041008.093740

Loneragan, J. F., \& Asher, C. J. (1967). Response of plants to phosphate concentration in solution culture: II. Rate of phosphate absorption and its relation to growth. Soil Science, 103(5), 311-318. https://doi.org/ 10.1097/00010694-196705000-00002

Mohammed, W. (2014). Genetic variability in potato (Solanum tuberosum L.) genotypes for late blight [Phytophthora infestans (Mont.) de Bary] resistance and yield at Haramaya, Eastern Ethiopia. East African Journal of Sciences, 8(1), 13-28.

Pavek, M. J., \& Thornton, R. E. (2009). Planting depth influences potato plant morphology and economic value. American Journal of Potato Research, 86(1), 56. https://doi.org/10.1007/s12230-008-9062-y

Po, E. A., Snapp, S. S., \& Kravchenko, A. (2010). Potato yield variability across the landscape. Agronomy Journal, 102(3), 885-894. https://doi.org/10.2134/agronj2009.0424

Rodríguez, S. J. (1993). Development of a Model of Zinc Dose Estimation in Corn (Zea mays L.) Crop.

Rosen, C. J., \& Bierman, P. M. (2008). Potato yield and tuber set as affected by phosphorus fertilization. American Journal of Potato Research, 85(2), 110-120. https://doi.org/10.1007/s12230-008-9001-y

Simane, B., Wortmann, C. W. S., \& Hoogenboom, G. (1998). Haricot bean agroecology in Ethiopia: Definition using agroclimatic and crop growth simulation models. African Crop Science Journal, 6(1), 9-18. https://doi.org/10.4314/acsj.v6i1.27820

Smith, O. (1977). Potatoes: Production, storing and processing (2nd ed.). The AVI Publishing Company, Westport, Connecticut, USA.

Tamire, H. (1973). Characterization of Alemaya Soils (Soil Science Paper, Series No. 1, p. 45).

Teressa. (1995). Sustainable Potato Production. Ecological Agriculture Projects, McGill University (Macdonald Campus). Journal of Pesticide Reform, 15(9).

Tesfaye, A., Yigzaw, D., \& Ermias, A. (2008). Crop management research and achievement on potato in Amhara Region with special reference to western Amhara parts (MSc Thesis, Department of Plant Sciences, College of Agriculture, Haramaya University, Ethiopia).

Vaezzadeh, M., \& Naderidarbaghshahi, M. (2012). The effect of various nitrogen fertilizer amounts on yield and nitrate accumulation in tubers of two potato cultivars in cold regions of Isfahan (Iran). International Journal of Agriculture and Crop Sciences, 4(22), 1688-1691.

Van der zaag. D. E., \& H. P. Beukema. (1989). Potato improvement some factors and facts (pp. 83-84). International Agriculture Center (IAC), Wagningen, The Netherland.

Vitosh, M. L., Paul, E. A., Harwood, R. R., \& Smucker, D. R. (1997). Nitrogen stewardship practices to reduce nitrate leaching and sustain profitability in an irrigated potato production system. In R. Chase (Ed.), Michigan Potato Research Report (Vol. 29, pp. 66-80). MSU and MPIC, Dewitt, Mich.

\section{Copyrights}

Copyright for this article is retained by the author(s), with first publication rights granted to the journal.

This is an open-access article distributed under the terms and conditions of the Creative Commons Attribution license (http://creativecommons.org/licenses/by/4.0/). 